\title{
ANALISIS EFEKTIFITAS DAN EFISIENSI PAJAK REKLAME, PAJAK PARKIR, PAJAK HIBURAN, PRODUK DOMESTIK REGIONAL BRUTO (PDRB) DAN PENDAPATAN ASLI DAERAH (PAD) DI KABUPATEN BANTUL
}

\author{
Teguh Erawati * \\ Nyemas Rahmawati \\ Program Studi Akuntansi Fakultas Ekonomi \\ Universitas Sarjanawiyata Tamansiswa \\ *eradimenicarch@gmail.com
}

\begin{abstract}
This study aims to determine the growth and role of Advertisement Tax, Tax Parkir and Entertainment Tax on Gross Regional Domestic Product (PDRB) and Revenue First Regional $(P A D)$ in Bantul. To determine the effectiveness and efficiency of the advertisement tax, Parking Tax, Entertainment Tax and Revenue First Regional (PAD) in Bantul. The variables of this research is the advertisement tax, Parkir Tax, Entertainment Tax Gross Regional Domestic Product (PDRB) and revenue First Regional (PAD). The research data is the data type sekuder years 2009 - 2014 was obtained from the study of literature, Dipenda Bantul and the Central Bureau of Statistics of Bantul.Teknik analysis is the analysis of the contribution, effectiveness, and efficiency. The results showed growth billboard tax ranging between $7.79 \%-54.91 \%$, or an average annual $18.09 \%$ advertisement tax contribution to the PDRB annually on average by $0,016 \%$. While the contribution of the advertisement tax to PAD which is an average of $1.528 \%$. Parkir tax growth ranged between $6.37 \%$ - $130.91 \%$ or an average annual $48.30 \%$ Parkir tax contribution to the GDP average of $0.00037 \%$. While the contribution of tax revenue parking against average of $0.031 \%$. The growth of the entertainment tax ranging between $7.78 \%-98.24 \%$ Average $47.83 \%$ in terms of entertainment tax contribution to the PDRB average of $0.000217 \%$. While the contribution of entertainment tax to PAD is the average per year amounted to $0.183 \%$ of the total revenue. Effectiveness analysis realization advertisement tax, tax and entertainment tax parking otherwise very effective, because the results of the calculation of the average in the past 6 years more than $100 \%$. The results of the analysis of the efficiency of the advertisement tax, tax parking and entertainment taxes very own efficient, because the result of calculation of 10\%, so it is very efficient because of below 60\%, in terms of the cost of harvesting minimal can produce revenues advertisement tax, tax parking and entertainment tax maximum.
\end{abstract}

Keywords: Advertisement tax, Parking Tax, Entertainment Tax, Gross Regional Domestic Product (PDRB) and Revenue First Regional (PAD)

\section{PENDAHULUAN}

Seiring dengan diberlakukannya otonomi daerah maka dikenal pula istilah desentralisasi fiskal. Desentralisasi fiskal berarti pendelegasian kewenangan dan tanggung jawab fiskal dari pemerintah pusat kepada pemerintah daerah. Dengan diberlakukannya kebijakan desentralisasi fiskal, maka daerah diberikan kebebasan untuk mengatur sistem pembiayaan dan pembangunan daerahnya sesuai dengan potensi dan kapasitasnya masing-masing. Untuk melaksanakan dan menyelenggarakan otonomi daerah secara nyata, luas dan bertanggung jawab diperlukan kewenangan dan kemampuan daerah untuk menggali sumber-sumber keuangan sendiri yang didukung oleh perimbangan keuangan antara pemerintah pusat dan pemerintah daerah. Dengan demikian, pemerintah daerah harus mampu menggali sumber-sumber keuangan sendiri agar dapat melaksanakan fungsinya secara efektif dan efisien, yakni dalam bidang pemerintahan dan pelayanan umum kepada masyarakat. 
Dalam rangka menyelanggarakan rumah tangganya sendiri, pemerintah daerah memerlukan dana yang tidak sedikit. Oleh karena itu pemerintah daerah harus mengoptimalkan sumber-sumber penerimaan daerah dalam era otonomi daerah dan desentralisasi fiskal.

Pendapatan Asli Daerah (PAD) merupakan salah satu indikator yang menentukan derajat kemandirian suatu daerah. Semakin besar penerimaan PAD suatu daerah maka semakin rendah tingkat ketergantungan pemerintah daerah tersebut terhadap pemerintah pusat. Sebaliknya, semakin rendah penerimaan PAD suatu daerah maka semakin tinggi tingkat ketergantungan pemerintah daerah tersebut terhadap pemerintah pusat. Hal ini dikarenakan PAD merupakan sumber penerimaan daerah yang berasal dari dalam daerah itu sendiri.

Menurut Peraturan Daerah Kabupaten Bantul Nomor 3 Tahun 2011 Tentang Pajak Hiburan, Pajak hiburan adalah pajak atas penyelenggaraan hiburan. Hiburan adalah semua jenis tontonan, pertunjukan, permainan dan/atau keramaian yang dinikmati dengan dipungut bayaran. Hiburan sebagaimana tersebut meliputi tontonan film, pagelaran kesenian, musik, dan tari modern; kesenian rakyat/tradisional; pagelaran busana, kontes kecantikan, binaraga, dan sejenisnya; pameran; diskotik, karaoke, klab malam, dan panti pijat; sirkus, akrobat, dan sulap; permainan bilyar, golf, dan boling; pacuan kuda, kendaraan bermotor, dan permainan ketangkasan; refleksi, mandi uap/spa, dan pusat kebugaran (fitness center); dan pertandingan olahraga.

Pemerintah Kabupaten Bantul melalui Dinas Pengelolaan Keuangan dan Aset Daerah (DPKAD) melakukan usaha-usaha peningkatan pajak-pajak tersebut secara optimal untuk mengisi kas daerah. Hal ini juga di dukung oleh perkembangan perekonomian yang meningkat di Kabupaten Bantul yang dapat dilihat dalam perkembangan PDRB Perkapita (Produk Domestik Regional Bruto). PDRB Perkapita merupakan jumlah nilai tambah yang dihasilkan oleh seluruh usaha dalam suatu wilayah, atau merupakan jumlah seluruh nilai dan jasa akhir yang di hasilkan oleh suatu daerah (BPS,2003).
Berdasarkan uraian di atas, maka penelitian skripsi ini memilih judul "Analisis Efektifitas dan Efisiensi Pajak Reklame, Pajak Parkir, Pajak Hiburan, Produk Domestik Regional Bruto (PDRB) dan Pendapatan Asli Daerah (PAD) di Kabupaten Bantul "dengan menganalisa hal berikut :

1. Bagaimana pertumbuhan dan peranan Pajak Reklame, Pajak Parkir dan Pajak Hiburan terhadap Produk Domestik Regional Bruto (PDRB) dan Pendapatan Asli Daerah (PAD) di Kabupaten Bantul?

2. Bagaimana efektifitas Pajak Reklame, Pajak Parkir, Pajak Hiburan dan Pendapatan Asli Daerah (PAD) di Kabupaten Bantul?

3. Bagaimana efisiensi Pajak Reklame, Pajak Parkir, Pajak Hiburan Pendapatan Asli Daerah (PAD) di Kabupaten Bantul?

\section{METODOLOGI PENELITIAN}

\section{Jenis Data dan Sumber Data}

Dalam penelitian ini data yang digunakan adalah data sekunder pada tahun 2009 - 2014 yang meliputi data pajak reklame, pajak parkir, pajak hiburan, PDRB dan PAD. Data tersebut diperoleh dari studi kepustakaan, Dipenda Kabupaten Bantul dan Biro Pusat Statistik Kabupaten Bantul.

\section{Variabel Penelitian dan Definisi Operasional Variabel}

Variabel yang digunakan dalam penelitian ini terdiri:

1. Pendapatan Asli Daerah (PAD) yaitu Pendapatan daerah yang bersumber dari hasil pajak daerah, hasil retribusi daerah, hasil pengelolaan kekayaan daerah yang dipisahkan, dan lain-lain PAD yang sah yang diukur dengan satuan Rupiah. Data diambil dari Dipenda Kabupaten Bantul.

2. Produk Domostik Ragional Bruto adalah nilai total barang dan jasa yang dihasilkan di Kabupaten Bantul selama satu tahun berdasarkan harg konstan, data diukur dengan satuan rupiah. Data diambil dari BPS Kabupaten Bantul.

3. Pajak Reklame adalah pajak atas penyelenggaraan reklame. Reklame adalah benda, alat, perbuatan atau media yang bentuk dan corak ragamnya dirancang untuk tujuan komersial memperkenalkan, 
menganjurkan, mempromosikan atau untuk menarik perhatian umum terhadap barang, jasa, orang atau badan, yang dapat dilihat, dibaca, didengar, dirasakan dan/atau dinikmati oleh umum yang diukur dengan satuan Rupiah. Data diambil dari Dipenda Kabupaten Bantul.

4. Pajak Parkir adalah pajak atas penyelenggaraan tempat parkir di luar badan jalan, baik yang disediakan berkaitan dengan pokok usaha maupun yang disediakan sebagai suatu usaha, termasuk penyediaan tempat penitipan kendaraan bermotor yang diukur dengan satuan Rupiah. Data diambil dari Dipenda Kabupaten Bantul

5. Pajak Hiburan adalah Pajak atas penyelenggaraan Hiburan. Hiburan merupakan semua jenis tontonan, pertunjukan, permainan, dan/atau keramaian yang dinikmati dengan dipungut bayaran yang diukur dengan satuan Rupiah. Data diambil dari Dipenda Kabupaten Bantul.

\section{Teknik Analisis Data}

Dalam penelitian ini akan digunakan analisis data kuantitatif yang diharapkan mampu memperoleh hasil yang cermat karena dilakukan dengan perhitungan dan analisis matematis, serta analisis data secara kualitatif untuk menganalisis data dalam bentuk uraian dengan menggunakan kata-kata.

\section{Uji Proporsi/Kontribusi}

Untuk mengetahui proporsi/kontrubusi pajak reklame, pajak Parkir dan pajak hiburan terhadap PDRB dan PAD digunakan analisis tabel anggaran, dengan cara membandingkan perkembangan angka-angka yang telah tersusun dalam suatu tabel anggaran. Untuk mengetahui kontribusi pajak reklame, pajak Parkir dan pajak hiburan terhadap PDRB dan PAD digunakan rumus :

$$
\text { Kontribusi }=\frac{\text { Penerimaan Pajak }}{\text { PDRB/PAD }} \times 100 \%
$$

\section{Tabel 1}

Kriteria Kontribusi

\begin{tabular}{cc}
\hline Presentase Kontribusi & Kriteria \\
\hline $0,00 \%-10 \%$ & Sangat Kurang \\
$10,10 \%-20 \%$ & Kurang \\
$20,10 \%-30 \%$ & Sedang \\
$30,10 \%-40 \%$ & Cukup Baik \\
$40,10 \%-50 \%$ & Baik \\
$>50 \%$ & Sangat Baik \\
\hline
\end{tabular}

Sumber : (Hakim, 2013)

\section{Uji Efesiensi dan Efektivitas}

Hasil guna (effektivitas) yaitu untuk mengukur hubungan antara hasil pungut pajak reklame, pajak Parkir dan pajak hiburan dan potensi pajak reklame, pajak Parkir dan pajak hiburan. Efektitas akan lebih baik jika tingkat efektifitasnya akan melebihi $100 \%$.

Rumus Efektifitas

$$
=\frac{\text { Realisasi penerimaan pajak }}{\text { Potensi/Target penerimaan Pajak }} \times 100 \%
$$

Daya guna (efisiensi) yaitu mengukur bagian dari hasil pajak yang digunakan untuk menutup biaya memungut pajak yang bersangkutan. Efisiensi akan lebih tinggi jika biaya ditekan serendah mungkin terhadap hasil Rumus Efisiensi

$$
=\frac{\text { Biay a pemungutan pajak }}{\text { Re alisasi penerimaan pajak }} \times 100 \%
$$

Tabel 2

Tabel Rasio Efektivitas dan Rasio Efisiensi

\begin{tabular}{cccc}
\hline $\begin{array}{c}\text { Rasio } \\
\text { Efektivitas }\end{array}$ & Kriteria & $\begin{array}{c}\text { Rasio } \\
\text { Efisiensi }\end{array}$ & Kriteria \\
\hline$>100 \%$ & Sangat Efektif & $>100 \%$ & Tidak Efisien \\
$>90 \%-100 \%$ & Efektif & $>90 \%-100 \%$ & Kurang Efisien \\
$>80 \%-90 \%$ & Cukup Efektif & $>80 \%-90 \%$ & Cukup Efisien \\
$>60 \%-80 \%$ & Kurang efektif & $>60 \%-80 \%$ & Efisien \\
$<60 \%$ & Tidak Efektif & $<60 \%$ & Sangat Efisien \\
\hline \multicolumn{2}{c}{ Sumber: (Hakim, 2013) } & &
\end{tabular}




\section{HASIL DAN PEMBAHASAN}

Analisis Kontribusi Pajak Reklame Terhadap Produk Domestik Regional Bruto (PDRB)

Tabel 3

\section{Kontribusi Pajak Reklame Terhadap Produk Domestik Regional Bruto (PDRB) Kabupaten} Bantul Tahun 2009- 2014

\begin{tabular}{llllll}
\hline \multirow{2}{*}{ Tahun } & \multicolumn{2}{c}{ Pajak Reklame } & \multicolumn{2}{c}{ PDRB } & \multirow{2}{*}{ Kotri (\%) } \\
\cline { 2 - 5 } & \multicolumn{1}{c}{ Jumlah (Rp) } & $\operatorname{Prb}(\%)$ & \multicolumn{1}{c}{ Jumlah (Rp) } & Prb (\%) & \\
\hline 2009 & $1.244 .917 .012,99$ & & 10.097 .345 .000 .000 & & 0,012 \\
2010 & $1.928 .535 .601,00$ & 54,91 & 12.114 .059 .100 .000 & 19,97 & 0,016 \\
2011 & $2.078 .745 .604,00$ & 7,79 & 13.290 .666 .600 .000 & 9,71 & 0,016 \\
2012 & $2.718 .571 .111,08$ & 30,78 & 14.510 .832 .400 .000 & 9,18 & 0,019 \\
2013 & $3.255 .704 .581,00$ & 19,76 & 16.138 .755 .100 .000 & 11,22 & 0,020 \\
2014 & $2.513 .332 .174,00$ & $-22,8$ & 17.977 .499 .100 .000 & 11,39 & 0,014 \\
Rerata & $2.289 .967 .680,68$ & 18,09 & $14.021 .526 .216 .666,70$ & 12,30 & 0,016 \\
\hline
\end{tabular}

Sumber : Data diolah

Pada tahun 2009 Kontribusi pajak Reklame terhadap PDRB sebesar 0,012\% dalam artian, total PDRB sebesar Rp 10.097.345.000.000. Tahun 2010 Kontribusi pajak reklame terhadap PDRB naik sebesar $0,016 \%$ hal ini dipengaruhi oleh naiknya penerimaan pajak reklame sebesar 54,91\% lebih besar dari pada kenaikkan PDRB yang hanya naik $19,97 \%$, kemudian tahun 2011 Kontribusi pajak reklame terhadap PDRB turun sebesar $0,016 \%$ hal ini dipengaruhi oleh kenaikkan pajak reklame sebesar $7,79 \%$ lebih kecil jika dibandingkan kenaikan PDRB sebesar 9,71\%. Pada tahun 2012 kembali naik menjadi 0,019\%, hal ini dipengaruhi oleh naiknya penerimaan pajak reklame sebesar 30,78\% lebih besar dari pada kenaikkan PDRB yang hanya naik 9,18\%.
Pada tahun 2013 kembali naik menjadi 0,020\%, hal ini dipengaruhi oleh naiknya penerimaan pajak reklame sebesar 19,76\% lebih besar dari pada kenaikkan PDRB yang hanya naik $11,22 \%$. Sedangkan tahun 2014 mengalami penurunan sebesar $0,014 \%$, hal ini dipengaruhi oleh penurunan pajak reklame sebesar $-22,80 \%$ sedangkan PDRB tetap naik sebesar 11,39\%.

Dengan demikian jika dirata-rata Kontribusi pajak reklame terhadap PDRB selama enam tahun yaitu tahun 2009- 2014 sebesar $0,016 \%$ pertahun. Jadi dapat disimpulkan Kontribusi pajak reklame masuk ketegori sangat kurang, karena masuk kriteria 0,00\%-10\%, dengan Produk Domestik Regional Bruto (PDRB) rata-rata pertahunnya sebesar Rp 2.289.967.680,68.

\section{Analisis Kontribusi Pajak Reklame Terhadap Pendapatan Asli Daerah Tabel 4}

Kontribusi Pajak Reklame Terhadap Pendapatan Asli Daerah Kabupaten Bantul Tahun 2009 - 2014

\begin{tabular}{|c|c|c|c|c|c|}
\hline \multirow{2}{*}{ Tahun } & \multicolumn{2}{|c|}{ Pajak Reklame } & \multicolumn{2}{|l|}{ PAD } & \\
\hline & Jumlah (Rp) & $\operatorname{Perbn}(\%)$ & Jumlah (Rp) & Perb $(\%)$ & \\
\hline 2009 & $1.244 .917 .012,99$ & & $88.691 .362 .690,00$ & & 1,404 \\
\hline 2010 & $1.928 .535 .601,00$ & 54,91 & 81.646.839.293,07 & $-7,94$ & 2,362 \\
\hline 2011 & $2.078 .745 .604,00$ & 7,79 & $128.896 .456 .173,41$ & 57,87 & 1,613 \\
\hline 2012 & 2.718.571.111,08 & 30,78 & $166.597 .778 .028,56$ & 29,25 & 1,632 \\
\hline 2013 & $3.255 .704 .581,00$ & 19,76 & $224.197 .857 .443,31$ & 34,57 & 1,452 \\
\hline 2014 & $2.513 .332 .174,00$ & $-22,80$ & $357.271 .829 .724,21$ & 59,36 & 0,703 \\
\hline Rerata & 2.289.967.680,68 & $18,09 \%$ & $174.550 .353 .892,09$ & 34,62 & 1,528 \\
\hline
\end{tabular}

\section{Sumber : Data diolah}

Dari perhitungan tabel di atas terhadap PAD berkisar antara 0,703\% sampai menunjukkan bahwa Kontribusi pajak Reklame 2,362\% sedangkan rata-rata Kontribusi pajak 
Reklame selama enam tahun terhadap PAD di Kabupaten Bantul adalah 1,528\% dari seluruh PAD, masuk ketegori sangat kurang, karena masuk kriteria 0,00\%-10\%. Apabila dilihat dari tahun-ketahun maka Kontribusi pajak Reklame terhadap PAD cenderung mengalami penurunan kecuali pada tahun 2010. Hal ini disebabkan karena kenaikan persentase penerimaan pajak Reklame diimbangi dengan penurunan PAD.

Analisis Kontribusi Pajak Parkir Terhadap Produk Domestik Regional Bruto (PDRB) Tabel 5

Kontribusi Pajak Parkir Terhadap Produk Domestik Regional Bruto (PDRB) Kabupaten Bantul Tahun 2009- 2014

\begin{tabular}{|c|c|c|c|c|c|}
\hline \multirow[b]{2}{*}{ Tahun } & \multicolumn{2}{|c|}{ Pajak Parkir } & \multicolumn{2}{|l|}{ PDRB } & \multirow{2}{*}{$\begin{array}{c}\text { Kont } \\
(\%)\end{array}$} \\
\hline & $\begin{array}{l}\text { Jumlah } \\
\text { (Rp) }\end{array}$ & $\begin{array}{c}\text { Perb } \\
(\%)\end{array}$ & $\begin{array}{l}\text { Jumlah } \\
\text { (Rp) }\end{array}$ & $\begin{array}{l}\text { Perb } \\
(\%)\end{array}$ & \\
\hline 2009 & $16.544 .500,00$ & & 10.097 .345 .000 .000 & & 0,00016 \\
\hline 2010 & $24.682 .000,00$ & 49,19 & 12.114 .059 .100 .000 & 19,97 & 0,00020 \\
\hline 2011 & $30.675 .000,00$ & 24,28 & 13.290 .666 .600 .000 & 9,71 & 0,00023 \\
\hline 2012 & $70.833 .088,40$ & 130,91 & 14.510 .832 .400 .000 & 9,18 & 0,00049 \\
\hline 2013 & $92.624 .866,00$ & 30,76 & 16.138 .755 .100 .000 & 11,22 & 0,00057 \\
\hline 2014 & $98.526 .370,00$ & 6,37 & 17.977.499.100.000 & 11,39 & 0,00055 \\
\hline Rerata & $55.647 .637,40$ & 48,30 & $14.021 .526 .216 .666,70$ & 12,30 & 0,00037 \\
\hline
\end{tabular}

Sumber : Data diolah

Pada tahun 2009 Kontribusi pajak Parkir terhadap PDRB sebesar 0,00016\%, yang diperoleh dari jumlah penerimaan pajak parkir sebesar 16.544.500,00/ total PDRB sebesar Rp 10.097.345.000.000 dikalikan 100\%. Tahun 2010 Kontribusi pajak Parkir terhadap PDRB naik sebesar $0,00020 \%$ hal ini dipengaruhi oleh naiknya penerimaan pajak Parkir sebesar 49,19\% lebih besar dari pada kenaikkan PDRB yang hanya naik 19,97\%, kemudian tahun 2011 Kontribusi pajak Parkir terhadap PDRB naik sebesar 0,00023\% hal ini dipengaruhi oleh kenaikkan pajak Parkir sebesar 24,28\% lebih besar jika dibandingkan kenaikan PDRB sebesar 9,71\%. Pada tahun 2012 kembali naik menjadi $0,00049 \%$, hal ini dipengaruhi oleh naiknya penerimaan pajak Parkir sebesar 130,91\% lebih besar dari pada kenaikkan PDRB yang hanya naik 9,18\%. Pada tahun 2013 kembali naik menjadi $0,00057 \%$, hal ini dipengaruhi oleh naiknya penerimaan pajak Parkir sebesar $30,76 \%$ lebih besar dari pada kenaikkan PDRB yang hanya naik $11,22 \%$. Sedangkan tahun 2014 mengalami penurunan sebesar 0,00055\%, hal ini dipengaruhi oleh kenaikkan pajak Parkir sebesar 6,37\% sedangkan PDRB naik sebesar $11,39 \%$.

Dengan demikian jika dirata-rata Kontribusi pajak Parkir terhadap PDRB selama enam tahun yaitu tahun 2009- 2014 sebesar $0,00037 \%$ pertahun. Jadi dapat disimpulkan Kontribusi pajak Parkir masuk ketegori sangat kurang, karena masuk kriteria 0,00\%-10\%, dengan Produk Domestik Regional Bruto (PDRB) rata-rata pertahunnya hanya $\mathrm{Rp}$ $55.647 .637,40$. 
Analisis Kontribusi Pajak Parkir Terhadap Pendapatan Asli Daerah

Tabel 6

Kontribusi Pajak Parkir Terhadap Pendapatan Asli Daerah

Kabupaten Bantul Tahun 2009 - 2014

\begin{tabular}{|c|c|c|c|c|c|}
\hline \multirow[b]{2}{*}{ Tahun } & \multicolumn{2}{|c|}{ Pajak Parkir } & \multicolumn{2}{|l|}{ PAD } & \multirow{2}{*}{$\begin{array}{c}\text { Kont } \\
(\%)\end{array}$} \\
\hline & $\begin{array}{l}\text { Jumlah } \\
\text { (Rp) }\end{array}$ & $\begin{array}{c}\text { Perb } \\
(\%)\end{array}$ & $\begin{array}{l}\text { Jumlah } \\
\text { (Rp) }\end{array}$ & $\begin{array}{c}\text { Perb } \\
(\%)\end{array}$ & \\
\hline 2009 & $16.544 .500,00$ & & $88.691 .362 .690,00$ & & 0,019 \\
\hline 2010 & $24.682 .000,00$ & 49,19 & $81.646 .839 .293,07$ & $-7,94$ & 0,030 \\
\hline 2011 & $30.675 .000,00$ & 24,28 & $128.896 .456 .173,41$ & 57,87 & 0,024 \\
\hline 2012 & $70.833 .088,40$ & 130,91 & $166.597 .778 .028,56$ & 29,25 & 0,043 \\
\hline 2013 & $92.624 .866,00$ & 30,76 & $224.197 .857 .443,31$ & 34,57 & 0,041 \\
\hline 2014 & $98.526 .370,00$ & 6,37 & $357.271 .829 .724,21$ & 59,36 & 0,028 \\
\hline Rerata & $55.647 .637,40$ & 48,30 & $174.550 .353 .892,09$ & 34,62 & 0,031 \\
\hline
\end{tabular}

Sumber : Data diolah

Dari perhitungan tabel di atas menunjukkan bahwa Kontribusi pajak Parkir terhadap PAD berkisar antara 0,019\% sampai 0,043\% sedangkan rata-rata Kontribusi pajak Parkir selama enam tahun terhadap PAD di Kabupaten Bantul adalah 0,031\% dari seluruh PAD, masuk ketegori sangat kurang, karena

masuk kriteria 0,00\%-10\%. Apabila dilihat dari tahun-ketahun maka Kontribusi pajak Parkir terhadap PAD cenderung mengalami kenaikkan kecuali pada tahun 2011 dan 2014. Hal ini disebabkan karena kenaikan persentase penerimaan pajak Parkir diimbangi dengan kanaikkan PAD.

Analisis Kontribusi Pajak Hiburan Terhadap Produk Domestik Regional Bruto (PDRB)

Tabel 7

Kontribusi Pajak Hiburan Terhadap Produk Domestik Regional Bruto (PDRB) Kabupaten Bantul Tahun 2009- 2014

\begin{tabular}{|c|c|c|c|c|c|}
\hline \multirow[b]{2}{*}{ Tahun } & \multicolumn{2}{|c|}{ Pajak Hiburan } & \multicolumn{2}{|l|}{ PDRB } & \multirow[b]{2}{*}{$\begin{array}{l}\text { Kont } \\
(\%)\end{array}$} \\
\hline & $\begin{array}{l}\text { Jumlah } \\
\text { (Rp) }\end{array}$ & $\begin{array}{c}\text { Perb } \\
(\%)\end{array}$ & $\begin{array}{l}\text { Jumlah } \\
\text { (Rp) }\end{array}$ & $\begin{array}{l}\text { Perb } \\
(\%)\end{array}$ & \\
\hline 2009 & $91.851 .050,00$ & & 10.097.345.000.000 & & 0,00091 \\
\hline 2010 & $149.914 .202,00$ & 63,21 & 12.114.059.100.000 & 19,97 & 0,00124 \\
\hline 2011 & 222.246.988,00 & 48,25 & 13.290.666.600.000 & 9,71 & 0,00167 \\
\hline 2012 & $440.593 .360,00$ & 98,24 & 14.510 .832 .400 .000 & 9,18 & 0,00304 \\
\hline 2013 & 474.855.491,60 & 7,78 & 16.138.755.100.000 & 11,22 & 0,00294 \\
\hline 2014 & $577.695 .506,00$ & 21,66 & 17.977.499.100.000 & 11,39 & 0,00321 \\
\hline Rerata & $326.192 .766,27$ & 47,83 & $14.021 .526 .216 .666,70$ & 12,30 & 0,00217 \\
\hline
\end{tabular}

Sumber : Data diolah

Pada tahun 2009 Kontribusi pajak hiburan terhadap PDRB sebesar 0,00091\%, yang diperoleh dari jumlah penerimaan pajak hiburan sebesar 91.851.050,00 dibagi total PDRB sebesar Rp 10.097.345.000.000 dikalikan 100\%. Tahun 2010 sampai 2014 Kontribusi pajak reklame terhadap PDRB menagalami kanaikan, hal ini dipengaruhi oleh naiknya penerimaan pajak hiburan lebih besar dari pada kenaikkan PDRB. Sedangkan pada tahun 2012 ke 2013 mengalami penurunan, hal ini karena kenaikkan pajak hiburan lebih kecil kenaikkan PDRB.

Dengan demikian jika dirata-rata Kontribusi pajak hiburan terhadap PDRB selama enam tahun yaitu tahun 2009- 2014 
sebesar $0,00217 \%$ pertahun. Jadi dapat disimpulkan Kontribusi pajak hiburan masuk ketegori sangat kurang, karena masuk kriteria
0,00\%-10\%, dengn Produk Domestik Regional Bruto (PDRB) rata-rata pertahunnya hanya $\mathrm{Rp}$ 326.192.766,27

\section{Analisis Kontribusi Pajak Hiburan Terhadap Pendapatan Asli Daerah} Tabel 8

Kontribusi Pajak Hiburan Terhadap Pendapatan Asli Daerah Kabupaten Bantul

Tahun 2009-2014

\begin{tabular}{|c|c|c|c|c|c|}
\hline \multirow[b]{2}{*}{ Tahun } & \multicolumn{2}{|l|}{ Pajak Hiburan } & \multicolumn{2}{|l|}{ PAD } & \multirow[b]{2}{*}{$\begin{array}{l}\text { Kont } \\
(\%)\end{array}$} \\
\hline & $\begin{array}{l}\text { Jumlah } \\
\text { (Rp) }\end{array}$ & $\begin{array}{l}\text { Perb } \\
(\%)\end{array}$ & $\begin{array}{l}\text { Jumlah } \\
\text { (Rp) }\end{array}$ & $\begin{array}{l}\text { Perb } \\
(\%)\end{array}$ & \\
\hline 2009 & $91.851 .050,00$ & & 88.691 .362 & & \\
\hline 2010 & $149.914 .202,00$ & 63,21 & 81.646 .839 & $-7,94$ & 0,184 \\
\hline 2011 & $222.246 .988,00$ & 48,25 & 128.896 .456 & 57,87 & 0,172 \\
\hline 2012 & $440.593 .360,00$ & 98,24 & $166.597 .778 .028,56$ & 29,25 & 0,264 \\
\hline 2013 & $474.855 .491,60$ & 7,78 & $224.197 .857 .443,31$ & 34,57 & 0,212 \\
\hline 2014 & $577.695 .506,00$ & 21,66 & $357.271 .829 .724,21$ & 59,36 & 0,162 \\
\hline Rerata & $326.192 .766,27$ & 47,83 & $174.550 .353 .892,09$ & 34,62 & 0,183 \\
\hline
\end{tabular}

Sumber : Data diolah

Dari perhitungan tabel $\mathrm{di}$ atas menunjukkan bahwa Kontribusi pajak hiburan terhadap PAD berkisar antara 0,104\% sampai $0,264 \%$ sedangkan rata-rata Kontribusi pajak hiburan selama enam tahun terhadap PAD di Kabupaten Bantul adalah 0,183\% dari seluruh PAD, masuk ketegori sangat kurang, karena masuk kriteria 0,00\%-10\%,. Apabila dilihat dari tahun-ketahun maka Kontribusi pajak hiburan terhadap PAD cenderung mengalami fluktuatif. Hal ini disebabkan karena kenaikan persentase penerimaan pajak Reklame diimbangi dengan kenaikkan PAD.

\section{Analisis Efektivitas \\ Efektivitas Pajak Reklame}

Salah satu tolak ukur pajak reklame adalah hasil guna (efektivitas). Efektivitas adalah perbandingan antara realisasi penerimaan pajak reklame dengan potensi yang kan dicapai. Berhubungan data potensi tidak ada, yang ada data target kami menggunakan target. Semakin besar penerimaan pajak reklame yang dapat direalisir dibandingkan target yang ditetapkan berarti pemungutan pajak reklame semakin berhasil atau, semakin efektif. Berikut ini disajikan perhitungan rasio efektivitas dari tahun-ketahun, dengan perhitungan sebagai berikut :

\section{Tabel 9}

Perhitungan Efektivitas Pajak Reklame

Kabupaten Bantul Tahun 2009-2014

\begin{tabular}{lllc} 
Tahun & Realisasi (Rp) & Target (Rp) & Efektivitas (\%) \\
\hline 2009 & $1.244 .917 .012,99$ & 1.230 .000 .000 & 101,21 \\
2010 & $1.928 .535 .601,00$ & 1.800 .000 .000 & 107,14 \\
2011 & $2.078 .745 .604,00$ & 2.000 .000 .000 & 103,94 \\
2012 & $2.718 .571 .111,08$ & 2.000 .000 .000 & 135,93 \\
2013 & $3.255 .704 .581,00$ & 2.100 .000 .000 & 155,03 \\
2014 & $2.513 .332 .174,00$ & 2.310 .000 .000 & 108,80 \\
Rerata & $2.289 .967 .680,68$ & $1.906 .666 .666,67$ & 118,68 \\
\hline
\end{tabular}

Sumber : Data diolah 
Dari hasil perhitungan yang terdapat dalam tabel di atas terlihat bahwa tingkat efektivitas pajak reklame Kabupaten Bantul dari tahun 2009 - 2014 berkisar antara 101,21\% sampai $155,03 \%$ dengan rata-rata efektivitas sebesar $118,68 \%$ pertahun. Hal ini berarti pelaksanaan pajak reklame di kabupaten Bantul telah dijalankan dengan sangat efektif. Dinyatakan sangat efektif karena menghasilkan rasio lebih besar dari $100 \%$.

Efektivitas Pajak Parkir

Salah satu tolak ukur pajak Parkir adalah hasil guna (efektivitas). Efektivitas adalah perbandingan antara realisasi penerimaan pajak Parkir dengan potensi yang kan dicapai. Berhubungan data potensi tidak ada, yang ada data target kami menggunakan target. Semakin besar penerimaan pajak Parkir yang dapat direalisir dibandingkan target yang ditetapkan berarti pemungutan pajak Parkir semakin berhasil atau, semakin efektif. Berikut ini disajikan perhitungan rasio efektivitas dari tahun-ketahun, dengan perhitungan sebagai berikut :

Tabel 10

Perhitungan Efektivitas Pajak Parkir Kabupaten Bantul Tahun 2009-2014

\begin{tabular}{lllc} 
Tahun & Realisasi (Rp) & Target (Rp) & Efektivitas (\%) \\
\hline 2009 & $16.544 .500,00$ & 15.000 .000 & 110,30 \\
2010 & $24.682 .000,00$ & 20.000 .000 & 123,41 \\
2011 & $30.675 .000,00$ & 25.000 .000 & 122,70 \\
2012 & $70.833 .088,40$ & 50.000 .000 & 141,67 \\
2013 & $92.624 .866,00$ & 75.000 .000 & 123,50 \\
2014 & $98.526 .370,00$ & 80.000 .000 & 123,16 \\
Rerata & $55.647 .637,40$ & $44.166 .666,67$ & 124,12 \\
\hline \multicolumn{5}{l}{ Sumber: Data diolah }
\end{tabular}

Dari hasil perhitungan yang terdapat dalam tabel di atas terlihat bahwa tingkat efektivitas pajak Parkir Kabupaten Bantul dari tahun 2009 - 2014 berkisar antara 110,30\% sampai $141,67 \%$ dengan rata-rata efektivitas sebesar $124,12 \%$ pertahun. Hal ini berarti

Salah satu tolak ukur pajak hiburan adalah hasil guna (efektivitas). Efektivitas adalah perbandingan antara realisasi penerimaan pajak hiburan dengan potensi yang kan dicapai. Berhubungan data potensi tidak ada, yang ada data target kami menggunakan target. Semakin besar penerimaan pajak hiburan yang dapat pelaksanaan pajak reklame di kabupaten Bantul telah dijalankan dengan sangat efektif. Dinyatakan sangat efektif karena menghasilkan rasio lebih besar dari $100 \%$.

\section{Efektivitas Pajak Hiburan}

direalisir dibandingkan target yang ditetapkan berarti pemungutan pajak hiburan semakin berhasil atau, semakin efektif. Berikut ini disajikan perhitungan rasio efektivitas dari tahun-ketahun, dengan perhitungan sebagai berikut : 


\section{Tabel 11}

\section{Perhitungan Efektivitas Pajak Hiburan Kabupaten Bantul Tahun 2009-2014}

\begin{tabular}{rrrc} 
Tahun & Realisasi (Rp) & Target (Rp) & Efektivitas $(\%)$ \\
\hline 2009 & $91.851 .050,00$ & 78.000 .000 & 117,76 \\
2010 & $149.914 .202,00$ & 130.000 .000 & 115,32 \\
2011 & $222.246 .988,00$ & 200.000 .000 & 111,12 \\
2012 & $440.593 .360,00$ & 400.000 .000 & 110,15 \\
2013 & $474.855 .491,60$ & 400.000 .000 & 118,71 \\
2014 & $577.695 .506,00$ & 500.000 .000 & 115,54 \\
Rerata & $326.192 .766,27$ & $284.666 .666,67$ & 114,77 \\
\hline
\end{tabular}

Sumber : Data diolah

Dari hasil perhitungan yang terdapat dalam tabel di atas terlihat bahwa tingkat efektivitas pajak hiburan Kabupaten Bantul dari tahun 2009 - 2014 berkisar antara 111,12\% sampai $118,71 \%$ dengan rata-rata efektivitas sebesar $114,77 \%$ pertahun. Hal ini berarti pelaksanaan pajak reklame di kabupaten Bantul telah dijalankan dengan sangat efektif. Dinyatakan sangat efektif karena menghasilkan rasio lebih besar dari $100 \%$.

\section{Efektivitas Pendapatan Asli Daerah (PAD)}

Salah satu tolak ukur Pendapatan Asli Daerah (PAD) adalah hasil guna (efektivitas).
Efektivitas adalah perbandingan antara realisasi penerimaan Pendapatan Asli Daerah (PAD) dengan potensi yang kan dicapai. Berhubungan data potensi tidak ada, yang ada data target kami menggunakan target. Semakin besar penerimaan Pendapatan Asli Daerah (PAD) yang dapat direalisir dibandingkan target yang ditetapkan berarti Pendapatan Asli Daerah (PAD) semakin berhasil atau, semakin efektif. Berikut ini disajikan perhitungan rasio efektivitas dari tahun-ketahun, dengan perhitungan sebagai berikut :

Tabel 12

Perhitungan Efektivitas Pendapatan Asli Daerah (PAD) Kabupaten Bantul Tahun 2009-2014

\begin{tabular}{rrrc} 
Tahun & Realisasi (Rp) & Target (Rp) & Efektivitas (\%) \\
\hline 2009 & $88.691 .362 .690,00$ & $77.286 .936 .022,99$ & 114,76 \\
2010 & $81.646 .839 .293,07$ & $89.015 .027 .964,59$ & 91,72 \\
2011 & $128.896 .456 .173,41$ & $115.321 .898 .743,75$ & 111,77 \\
2012 & $166.597 .778 .028,56$ & $141.624 .239 .103,47$ & 117,63 \\
2013 & $224.197 .857 .443,31$ & $205.407 .209 .787,07$ & 109,15 \\
2014 & $357.271 .829 .724,21$ & $228.058 .728 .992,34$ & 156,66 \\
Rerata & $174.550 .353 .892,09$ & $142.785 .673 .435,70$ & 116,95 \\
\hline Sur
\end{tabular}

Sumber : Data diolah

Dari hasil perhitungan yang terdapat dalam tabel di atas terlihat bahwa tingkat efektivitas Pendapatan Asli Daerah (PAD) di Kabupaten Bantul dari tahun 2009 - 2014 berkisar antara 91,72\% sampai $117,77 \%$ dengan rata-rata efektivitas sebesar 116,95\% pertahun. Hal ini berarti Pendapatan Asli Daerah (PAD) di Kabupaten Bantul sangat efektif. Dinyatakan sangat efektif karena menghasilkan rasio lebih besar dari $100 \%$. 


\section{Analisis Efisiensi}

\section{Efisiensi Pajak Reklame}

Efisiensi menunjukkan perbandingan antara biaya pemungutan dengan realisasi penerimaan pajak reklame

Tabel 13

Perhitungan Efisiensi Pajak Reklame Kabupaten Bantul Tahun 2009-2014

\begin{tabular}{rrrr} 
Tahun & Realisasi (Rp) & Biaya 10\% (Realisasi) & Efisiensi (\%) \\
\hline 2009 & $1.244 .917 .012,99$ & 124.491 .701 & 10 \\
2010 & $1.928 .535 .601,00$ & 192.853 .560 & 10 \\
2011 & $2.078 .745 .604,00$ & 207.874 .560 & 10 \\
2012 & $2.718 .571 .111,08$ & 271.857 .111 & 10 \\
2013 & $3.255 .704 .581,00$ & 325.570 .458 & 10 \\
2014 & $2.513 .332 .174,00$ & 251.333 .217 & 10 \\
Rerata & $2.289 .967 .680,68$ & $228.996 .768,07$ & 10 \\
\hline
\end{tabular}

Sumber : Data diolah

Berdasarkan tabel di atas dapat dilihat efisien. Dikatakan sangat efisien karena bahwa tingkat efisiensi pemungutan pajak memiliki rasio efisiensi dibawah $60 \%$, artinya reklame Kabupaten Bantul selama tahun 2009- biaya pemungutan pajak yang minimal dapat 2014 adalah 10\% dimana ini berarti bahwa memenuhi target yang maksimal. pajak reklame adalah jenis pajak yang sangat

\section{Efisiensi Pajak Parkir}

\section{Tabel 14}

Perhitungan Efisiensi Pajak Parkir Kabupaten Bantul Tahun 2009-2014

Tahun Realisasi (Rp) Biaya 10\% (Realisasi) Efisiensi (\%)

\begin{tabular}{rrrl}
\hline 2009 & $16.544 .500,00$ & 1.654 .450 & 10 \\
2010 & $24.682 .000,00$ & 2.468 .200 & 10 \\
2011 & $30.675 .000,00$ & 3.067 .500 & 10 \\
2012 & $70.833 .088,40$ & 7.083 .309 & 10 \\
2013 & $92.624 .866,00$ & 9.262 .487 & 10 \\
2014 & $98.526 .370,00$ & 9.852 .637 & 10 \\
Rerata & $55.647 .637,40$ & $5.564 .763,74$ & 10 \\
\hline
\end{tabular}

Sumber : Data diolah

Berdasarkan tabel di atas dapat dilihat bahwa tingkat efisiensi pemungutan pajak Parkir Kabupaten Bantul selama tahun 20092014 adalah 10\% dimana ini berarti bahwa pajak Parkir adalah jenis pajak yang sangat efisien. Dikatakan sangat efisien karena memiliki rasio efisiensi dibawah $60 \%$, artinya biaya pemungutan pajak yang minimal dapat memenuhi target yang maksimal. 


\section{Efisiensi Pajak Hiburan}

\section{Tabel 15}

\section{Perhitungan Efisiensi Pajak Hiburan Kabupaten Bantul Tahun 2009-2014}

Tahun Realisasi (Rp) Biaya 10\% (Realisasi) Efisiensi (\%)

\begin{tabular}{rrrl}
\hline 2009 & $91.851 .050,00$ & 9.185 .105 & 10 \\
2010 & $149.914 .202,00$ & 14.991 .420 & 10 \\
2011 & $222.246 .988,00$ & 22.224 .699 & 10 \\
2012 & $440.593 .360,00$ & 44.059 .336 & 10 \\
2013 & $474.855 .491,60$ & 47.485 .549 & 10 \\
2014 & $577.695 .506,00$ & 57.769 .551 & 10 \\
Rerata & $326.192 .766,27$ & $32.619 .276,63$ & 10 \\
\hline
\end{tabular}

Sumber : Data diolah

Berdasarkan tabel di atas dapat dilihat bahwa tingkat efisiensi pemungutan pajak hiburan Kabupaten Bantul selama tahun 20092014 adalah $10 \%$ dimana ini berarti bahwa pajak hiburan adalah jenis pajak yang sangat efisien. Dikatakan sangat efisien karena memiliki rasio efisiensi dibawah $60 \%$, artinya biaya pemungutan pajak yang minimal dapat memenuhi target yang maksimal.

\section{Efisiensi Pendapatan Asli Daerah (PAD)}

Efisiensi menunjukkan perbandingan antara biaya pemungutan dengan realisasi penerimaan Pendapatan Asli Daerah (PAD).

Tabel 16

Perhitungan Efisiensi Pendapatan Asli Daerah (PAD) Kabupaten Bantul Tahun 2009-2014

Tahun Realisasi (Rp) Biaya 10\% (Realisasi) Efisiensi (\%)

\begin{tabular}{rrrl}
\hline 2009 & $91.851 .050,00$ & 9.185 .105 & 10 \\
2010 & $149.914 .202,00$ & 14.991 .420 & 10 \\
2011 & $222.246 .988,00$ & 22.224 .699 & 10 \\
2012 & $440.593 .360,00$ & 44.059 .336 & 10 \\
2013 & $474.855 .491,60$ & 47.485 .549 & 10 \\
2014 & $577.695 .506,00$ & 57.769 .551 & 10 \\
Rerata & $326.192 .766,27$ & $32.619 .276,63$ & 10 \\
\hline
\end{tabular}

Sumber : Data diolah

Berdasarkan tabel di atas dapat dilihat bahwa tingkat efisiensi Pendapatan Asli Daerah (PAD) di Kabupaten Bantul selama tahun 2009. 2014 adalah 10\% dimana ini berarti bahwa Pendapatan Asli Daerah (PAD) adalah jenis pendapatan yang sangat efisien. Dikatakan sangat efisien karena memiliki rasio efisiensi dibawah $60 \%$, artinya biaya pemungutan pajak yang minimal dapat memenuhi target yang maksimal.

\section{Analisis Elastisitas}

\section{Elastisitas Pajak Reklame Terhadap PAD}

Elastisitas digunakan untuk mengetahui besarnya derajat kepekaan dari tingkat pengaruh variabel independen terhadap variabel dependen. Untuk mengetahui sejauhmana tingkat elastisitas penerimaan pajak rekleme terhadap Pendapatan Asli Daerah (PAD), maka dilakukan analisis melalui perhitungan sebagai berikut : 
Tabel 17

Elastisitas Pajak Reklame Terhadap PAD Kabupaten Bantul Tahun 2009-2014

\begin{tabular}{|c|c|c|c|c|c|}
\hline \multirow[b]{2}{*}{ Tahun } & \multicolumn{2}{|c|}{ Pajak Reklame } & \multicolumn{2}{|l|}{ PAD } & \multirow[b]{2}{*}{$\begin{array}{c}\text { Elasti } \\
(\%)\end{array}$} \\
\hline & $\begin{array}{l}\text { Jumlah } \\
\text { (Rp) }\end{array}$ & $\begin{array}{l}\text { Perb } \\
(\%)\end{array}$ & $\begin{array}{l}\text { Jumlah } \\
\text { (Rp) }\end{array}$ & $\begin{array}{l}\text { Perb } \\
(\%)\end{array}$ & \\
\hline 2009 & $1.244 .917 .012,99$ & & $88.691 .362 .690,00$ & & \\
\hline 2010 & $1.928 .535 .601,00$ & 54,91 & $81.646 .839 .293,07$ & $-7,94$ & $-6,914$ \\
\hline 2011 & $2.078 .745 .604,00$ & 7,79 & $128.896 .456 .173,41$ & 57,87 & 0,135 \\
\hline 2012 & 2.718.571.111,08 & 30,78 & $166.597 .778 .028,56$ & 29,25 & 1,052 \\
\hline 2013 & $3.255 .704 .581,00$ & 19,76 & $224.197 .857 .443,31$ & 34,57 & 0,571 \\
\hline 2014 & $2.513 .332 .174,00$ & $-22,80$ & $357.271 .829 .724,21$ & 59,36 & $-0,384$ \\
\hline Rerata & $2.289 .967 .680,68$ & & & & $-1,108$ \\
\hline
\end{tabular}

Sumber : Data diolah

Dari tabel di atas dapat dilihat dari tahun 2009 sampai 2014 besarnya elastisitas pada pajak reklame terhadap PAD masih dalam kondisi yang naik turun, besarnya lebih kecil dari 1 sehingga elastisitasnya bersifat inelastis. Untuk tahun 2009 besarnya elastisitas sebesar 6,914 berarti bersifat elastis, artinya yakni apabila jumlah PAD dari tahun 2009 mengalami penurunan sebesar $1 \%$ dan faktor-faktor lainnya tetap, maka penerimaan pajak reklme kenaikan

\section{Elastisitas Pajak Parkir Terhadap PAD}

Elastisitas digunakan untuk mengetahui besarnya derajat kepekaan dari tingkat pengaruh variabel independen terhadap variabel dependen. Untuk mengetahui sejauhmana tingkat elastisitas penerimaan pajak Parkir terhadap Pendapatan Asli Daerah (PAD), maka dilakukan analisis melalui perhitungan sebagai berikut : sebesar 6,914\%.

\section{Tabel 18}

Elastisitas Pajak Parkir Terhadap PAD Kabupaten Bantul Tahun 2009-2014

\begin{tabular}{|c|c|c|c|c|c|}
\hline \multirow[b]{2}{*}{ Tahun } & \multicolumn{2}{|c|}{ Pajak Parkir } & \multicolumn{2}{|l|}{ PAD } & \multirow{2}{*}{$\begin{array}{c}\text { Elastis } \\
(\%)\end{array}$} \\
\hline & $\begin{array}{l}\text { Jumlah } \\
\text { (Rp) }\end{array}$ & $\begin{array}{c}\text { Perb } \\
(\%)\end{array}$ & $\begin{array}{l}\text { Jumlah } \\
\text { (Rp) }\end{array}$ & $\begin{array}{l}\text { Perb } \\
(\%)\end{array}$ & \\
\hline 2009 & $16.544 .500,00$ & & $88.691 .362 .690,00$ & & \\
\hline 2010 & $24.682 .000,00$ & 49,19 & $81.646 .839 .293,07$ & $-7,94$ & $-6,193$ \\
\hline 2011 & $30.675 .000,00$ & 24,28 & $128.896 .456 .173,41$ & 57,87 & 0,420 \\
\hline 2012 & $70.833 .088,40$ & 130,91 & $166.597 .778 .028,56$ & 29,25 & 4,476 \\
\hline 2013 & $92.624 .866,00$ & 30,76 & $224.197 .857 .443,31$ & 34,57 & 0,890 \\
\hline 2014 & $98.526 .370,00$ & 6,37 & $357.271 .829 .724,21$ & 59,36 & 0,107 \\
\hline Rerata & $55.647 .637,40$ & & & & $-0,060$ \\
\hline
\end{tabular}

Sumber : Data diolah

Dari tabel di atas dapat dilihat dari tahun 2009 sampai 2014 besarnya elastisitas pada pajak Parkir terhadap PAD masih dalam kondisi yang naik turun, rata-rata besarnya lebih kecil dari 1 sehingga elastisitasnya bersifat inelastis. Untuk tahun 2009 besarnya elastisitas sebesar 6,193 berarti bersifat elastis, artinya yakni apabila jumlah PAD dari tahun 2009 mengalami penurunan sebesar $1 \%$ dan faktor-faktor lainnya tetap, maka penerimaan pajak reklme kenaikan sebesar $6,193 \%$.

\section{Elastisitas Pajak Hiburan Terhadap PAD}

Elastisitas digunakan untuk mengetahui besarnya derajat kepekaan dari tingkat pengaruh variabel independen terhadap variabel dependen. Untuk mengetahui sejauhmana tingkat elastisitas penerimaan pajak hiburan terhadap Pendapatan Asli Daerah 
(PAD), maka dilakukan analisis melalui perhitungan sebagai berikut :

Tabel 19

Elastisitas Pajak Hiburan Terhadap PAD Kabupaten Bantul Tahun 2009-2014

\begin{tabular}{|c|c|c|c|c|c|}
\hline \multirow[b]{2}{*}{ Tahun } & \multicolumn{2}{|c|}{ Pajak Hiburan } & \multicolumn{2}{|l|}{ PAD } & \multirow[b]{2}{*}{$\begin{array}{l}\text { Elastis } \\
(\%)\end{array}$} \\
\hline & $\begin{array}{l}\text { Jumlah } \\
\text { (Rp) }\end{array}$ & $\begin{array}{c}\text { Perb } \\
(\%)\end{array}$ & $\begin{array}{c}\text { Jumlah } \\
\text { (Rp) }\end{array}$ & $\begin{array}{l}\text { Perb } \\
(\%)\end{array}$ & \\
\hline 2009 & $91.851 .050,00$ & & $88.691 .362 .690,00$ & & \\
\hline 2010 & $149.914 .202,00$ & 63,21 & 81.646.839.293,07 & $-7,94$ & $-7,959$ \\
\hline 2011 & $222.246 .988,00$ & 48,25 & $128.896 .456 .173,41$ & 57,87 & 0,834 \\
\hline 2012 & $440.593 .360,00$ & 98,24 & 166.597.778.028,56 & 29,25 & 3,359 \\
\hline 2013 & $474.855 .491,60$ & 7,78 & $224.197 .857 .443,31$ & 34,57 & 0,225 \\
\hline 2014 & $577.695 .506,00$ & 21,66 & $357.271 .829 .724,21$ & 59,36 & 0,365 \\
\hline Rerata & $326.192 .766,27$ & & & & $-0,635$ \\
\hline
\end{tabular}

Sumber : Data diolah

Dari tabel di atas dapat dilihat dari tahun 2009 sampai 2014 besarnya elastisitas pada pajak Parkir terhadap PAD masih dalam kondisi yang naik turun, rata-rata besarnya lebih kecil dari 1 sehingga elastisitasnya bersifat inelastis. Untuk tahun 2009 besarnya elastisitas sebesar 7,959 berarti bersifat elastis, artinya yakni apabila jumlah PAD dari tahun 2009 mengalami penurunan sebesar $1 \%$ dan faktor-faktor lainnya tetap, maka penerimaan pajak reklme kenaikan sebesar 7,959\%.

\section{Elastisitas Pajak Reklame Terhadap PDRB}

Elastisitas digunakan untuk mengetahui besarnya derajat kepekaan dari tingkat pengaruh variabel independen terhadap variabel dependen. Untuk mengetahui sejauhmana tingkat elastisitas penerimaan pajak reklame terhadap Produk Domestik Ragional Bruto (PDRB), maka dilakukan analisis melalui perhitungan sebagai berikut :

Tabel 20

Elastisitas Pajak Reklame Terhadap PDRB Kabupaten Bantul Tahun 2009-2014

\begin{tabular}{rccccc}
\hline \multirow{2}{*}{ Tahun } & \multicolumn{2}{c}{ Pajak Reklame } & \multicolumn{2}{c}{ PDRB } & \multirow{2}{*}{ Elastis (\%) } \\
\cline { 2 - 5 } & Jumlah (Rp) & Perb (\%) & Jumlah (Rp) & Perb (\%) & \\
\hline 2009 & $1.244 .917 .012,99$ & & 10.097 .345 .000 .000 & & \\
2010 & $1.928 .535 .601,00$ & 54,91 & 12.114 .059 .100 .000 & 19,97 & 2,749 \\
2011 & $2.078 .745 .604,00$ & 7,79 & 13.290 .666 .600 .000 & 9,71 & 0,802 \\
2012 & $2.718 .571 .111,08$ & 30,78 & 14.510 .832 .400 .000 & 9,18 & 3,353 \\
2013 & $3.255 .704 .581,00$ & 19,76 & 16.138 .755 .100 .000 & 11,22 & 1,761 \\
2014 & $2.513 .332 .174,00$ & $-22,80$ & 17.977 .499 .100 .000 & 11,39 & $-2,001$ \\
Rerata & $2.289 .967 .680,68$ & & & & \\
\hline
\end{tabular}

Sumber : Data diolah

Dari tabel di atas dapat dilihat dari tahun 2009 sampai 2014 besarnya elastisitas pada pajak reklame terhadap PDRB masih dalam kondisi yang naik turun, rata-rata besarnya lebih besar dari 1 sehingga elastisitasnya bersifat elastis. Untuk tahun 2009 besarnya elastisitas sebesar 2,7499 berarti bersifat elastis, artinya yakni apabila jumlah PDRB dari tahun 2009 mengalami kenaikkan sebesar $1 \%$ dan faktor- faktor lainnya tetap, maka penerimaan pajak reklme naik sebesar 2,7499\%.

\section{Elastisitas Pajak Parkir Terhadap PDRB}

Elastisitas digunakan untuk mengetahui besarnya derajat kepekaan dari tingkat pengaruh variabel independen terhadap variabel dependen. Untuk mengetahui sejauhmana tingkat elastisitas penerimaan pajak Parkir terhadap Produk Domestik Ragional 
Bruto (PDRB), maka dilakukan analisis melalui perhitungan sebagai berikut:

Tabel 21

Elastisitas Pajak Parkir Terhadap PDRB Kabupaten Bantul Tahun 2009-2014

\begin{tabular}{llllll}
\hline \multirow{2}{*}{ Tahun } & \multicolumn{2}{c}{ Pajak Parkir } & \multicolumn{2}{c}{ PDRB } & \multirow{2}{*}{ Elastis (\%) } \\
\cline { 2 - 5 } & Jumlah (Rp) & Perb (\%) & \multicolumn{1}{c}{ Jumlah (Rp) } & Perb (\%) & \\
\hline 2009 & $16.544 .500,00$ & & 10.097 .345 .000 .000 & & \\
2010 & $24.682 .000,00$ & 49,19 & 12.114 .059 .100 .000 & 19,97 & 2,463 \\
2011 & $30.675 .000,00$ & 24,28 & 13.290 .666 .600 .000 & 9,71 & 2,500 \\
2012 & $70.833 .088,40$ & 130,91 & 14.510 .832 .400 .000 & 9,18 & 14,260 \\
2013 & $92.624 .866,00$ & 30,76 & 16.138 .755 .100 .000 & 11,22 & 2,742 \\
2014 & $98.526 .370,00$ & 6,37 & 17.977 .499 .100 .000 & 11,39 & 0,559 \\
Rerata & $55.647 .637,40$ & & & & 4,505
\end{tabular}

Sumber : Data diolah

Dari tabel di atas dapat dilihat dari tahun 2009 sampai 2014 besarnya elastisitas pada pajak Parkir terhadap PDRB masih dalam kondisi yang naik turun, rata-rata besarnya lebih besar dari 1 sehingga elastisitasnya bersifat elastis. Untuk tahun 2009 besarnya elastisitas sebesar 2,463 berarti bersifat elastis, artinya yakni apabila jumlah PDRB dari tahun 2009 mengalami kenaikkan sebesar 1\% dan faktor-faktor lainnya tetap, maka penerimaan pajak Parkir naik sebesar 2,463\%.

Elastisitas Pajak Hiburan Terhadap PDRB

Elastisitas digunakan untuk mengetahui besarnya derajat kepekaan dari tingkat pengaruh variabel independen terhadap variabel dependen. Untuk mengetahui sejauhmana tingkat elastisitas penerimaan pajak hiburan terhadap Produk Domestik Ragional Bruto (PDRB), maka dilakukan analisis melalui perhitungan sebagai berikut:

Tabel 22

Elastisitas Pajak Hiburan Terhadap PDRB Kabupaten Bantul Tahun 2009-2014

\begin{tabular}{llllll}
\hline \multirow{2}{*}{ Tahun } & Pajak Hiburan & \multicolumn{3}{l}{ PDRB } & \multirow{2}{*}{ Elastis (\%) } \\
\cline { 2 - 5 } & Jumlah (Rp) & Perb (\%) & Jumlah (Rp) & Perb (\%) & \\
\hline 2009 & $91.851 .050,00$ & & 10.097 .345 .000 .000 & & \\
2010 & $149.914 .202,00$ & 63,21 & 12.114 .059 .100 .000 & 19,97 & 3,165 \\
2011 & $222.246 .988,00$ & 48,25 & 13.290 .666 .600 .000 & 9,71 & 4,968 \\
2012 & $440.593 .360,00$ & 98,24 & 14.510 .832 .400 .000 & 9,18 & 10,701 \\
2013 & $474.855 .491,60$ & 7,78 & 16.138 .755 .100 .000 & 11,22 & 0,693 \\
2014 & $577.695 .506,00$ & 21,66 & 17.977 .499 .100 .000 & 11,39 & 1,901 \\
Rerata & $326.192 .766,27$ & & & & 4,286 \\
\hline
\end{tabular}

Sumber : Data diolah

Dari tabel di atas dapat dilihat dari tahun 2009 sampai 2014 besarnya elastisitas pada pajak hiburan terhadap PDRB masih dalam kondisi yang naik turun, rata-rata besarnya lebih besar dari 1 sehingga elastisitasnya bersifat elastis. Untuk tahun 2009 besarnya elastisitas sebesar 3,165 berarti bersifat elastis, artinya yakni apabila jumlah PDRB dari tahun 2009 mengalami kenaikkan sebesar $1 \%$ dan faktorfaktor lainnya tetap, maka penerimaan pajak hiburan naik sebesar 3,165\%.

\section{KESIMPULAN}

Dari hasil analisis data dapat diambil beberapa kesimpulan sebagai berikut :

1. Pertumbuhan pajak reklame berkisar antara $7,79 \%$ - 54,91\% atau rata-rata pertahunnya $18,09 \%$ dilihat dari kontribusi pajak reklame terhadap PDRB pertahunnya rata-rata sebesar $0,016 \%$. Sedangkan kontribusi pajak reklame terhadap PAD yaitu rata-rata pertahunnya sebesar $1,528 \%$ dari seluruh PAD. 
2. Pertumbuhan pajak Parkir berkisar antara $6,37 \%-130,91 \%$ atau rata-rata pertahunnya 48,30\% dilihat dari kontribusi pajak Parkir terhadap PDRB pertahunnya rata-rata sebesar $0,00037 \%$. Sedangkan kontribusi pajak Parkir terhadap PAD yaitu rata-rata pertahunnya sebesar $0,031 \%$ dari seluruh PAD.

3. Pertumbuhan pajak hiburan berkisar antara $7,78 \%$ - 98,24\% atau rata-rata pertahunnya $47,83 \%$ dilihat dari kontribusi pajak hiburan terhadap PDRB pertahunnya rata-rata sebesar $0,000217 \%$. Sedangkan kontribusi pajak hiburan terhadap PAD yaitu rata-rata pertahunnya sebesar $0,183 \%$ dari seluruh PAD.

4. Analisis efektivitas realisasi pajak reklame, pajak Parkir, pajak hiburan dan PAD dinyatakan sangat efektif, karena hasil perhitungan rata-rata dalam 6 tahun lebih dari $100 \%$.

5. Hasil analisis efisiensi pajak reklame, pajak Parkir, pajak hiburan dan PAD sangat efisien, karena hasil perhitungan sebesar $10 \%$ lebih kecil 60\%, sehingga sagat efisien, artinya dengan biaya pemungutan yang minimal dapat menghasilkan penerimaan pajak reklame, pajak Parkir, pajak hiburan dan PAD yang maksimal.

\section{Saran}

1. Perlu ditingkatkannya pelayanan pajak yang sistematis kepada para wajib pajak agar lebih mudah dalam pengurusan administrasi akan kewajiban pajaknya.

2. Pihak berwenang agar memperluas tempat reklame, memperluas wilayah perParkir an, dan wahana hiburan, yang dapat di nikmati masyarakat yang lebih luas, sehingga pajak pajak reklame, pajak Parkir dan pajak hiburan dapat di gali dari meningkatnya pengguna jasa reklame, perParkir an dan hiburan.

\section{Keterbatasan Penelitian}

Penelitian ini dalam mengumpulkan data mengalami keterbatasan atau kendala. Ada pun kendala-kendala tersebut adalah pertama, perolehan data dari Dipenda yang tidak lengkap termasuk perhitungan potensi yang tidak ada, sehingga menggunakan data target. Kedua tidak adanya data biaya pemungutan yang terinci, hanya ada biaya pemungutan diambil dari $10 \%$ dari realisasi. Ketiga tidak adanya pengadministrasian yang secara rinci atau terpisah untuk kegiatan belanja pemerintah daerah baik itu pegawai, peralatan, dan perlengkapan kantor yang secara langsung berhubungan dengan usaha pemerintah daerah dalam meningkatkan pendapatan asli daerah dari kegiatan pemerintah dalam melakukan kewajiban lain dalam pelayanan masyarakat dan kegiatan pembangunan daerah di Kabupaten Bantul.

\section{DAFTAR PUSTAKA}

Badan Pusat Statistik. 2015. Bantul Dalam Angka. Kabupaten Bantul .

Danied Mikha (2010), Analisis Kontribusi Pajak Dan Retribusi Daerah Terhadap Pendapatan Asli Daerah Kabupaten Sleman, Kajian Akuntansi, Volume 5, Nomor 1.

Ghofir, Abdul. 2000. Optimalisasi Pajak dalam Penerapan Otonomi Daerah. Berita Pajak No. 1411/Tahun XXXII/15 Januari 2000.

Ghozali, Imam. 2005. Aplikasi Analisis Multivariate dengan program SPSS, Badan. Penerbit Universitas Diponegoro, Semarang.

Gujarati, Damodar. 2003, Econometric, Erlangga, Jakarta.

Istianto, Donna Dwi 2011. Analisis FaktorFaktor Yang Mempengaruhi Penerimaan Pajak Reklame Di Kabupaten Semarang Tahun 20002009. Skripsi Fakultas Ekonomi

Kuncoro, Mudrajad, 2001, Metode Kuantitatif (Teori dan Aplikasi untuk Bisnis dan. Ekonomi), Yogyakarta : UPP AMP YKPM

Mardiasmo. 2003. Perpajakan. Yogyakarta: Andi Yogyakarta.

Musgrave, R.A., Musgrave, P.B., 1993, Keuangan Negara Dalam Teori dan Praktek,. Jakarta, Penerbit Penerbit Erlangga

Nurmayasari, Dini, 2010. Analisis Penerimaan Pajak Reklame Kota Semarang. Skripsi Fakultas Ekonomi Universitas Diponegoro Semarang 
Prakosa, Kesit Bambang. 2005, Pajak dan Retribusi Daerah, Penerbit Ull Press: Jakarta

Siahaan, Marihot P, 2005. Pajak dan Retribusi Daerah. Jakarta: Raja Grafindo Persada.

Sofian, Syuhada, 1997, Prospek dan Alternatif "Action Plan" Pemajakan Reklame dalam Mendongkrak Pendapatan Asli Daerah Studi Kasus Kodya Semarang, Gema Stikubank, Semarang.

Sunarto, 2005, Pajak dan Retribusi Daerah, Amus Yogyakarta dan Citra Pustaka Yogyakarta. Sutrisno (2002

Susanto A.B, Ghifari A.B, Susanto A, Suradinata E, Wijanarko H, Supranto J, Karmaji, Oyong R, Nurbaya $\mathrm{S}$ dan Martha S, 2010, Reinvensi pembangunan ekonomi daerah, Esensi Erlangga Group, Jakarta

Mourin M. Mosal (2013), Analisis Efektivitas, Kontribusi Pajak Parkir Terhadap Pendapatan Asli Daerah (PAD) Dan Penerapan Akuntansi Di Kota Manado,
Jurnal EMBA Vol.1 No.4 Desember 2013, Hal. 374-382

Muh. Rais (2012), Analisis Daya Pajak Dan Efektivitas Pajak Daerah Di Kabupaten Maros, Skripsi, Fakultas Ekonomi,Universitas Hasanuddin.

Hakim, Vita Amaliah. 2013. Analisis Efektivitas dan Efisiensi Pajak Daerah dan Retribusi Daerah Terhadap Pendapatan Asli Daerah Kota Tasikmalaya (Studi Kasus Pada Dinas Pendapatan Kota Tasikmalaya) Program Studi Akuntansi Fakultas Ekonomi. Universitas Siliwangi

Putry, Nurrahmah., dan Abdullah. 2011. Peranan Pajak Daerah dan Retribusi Daerah di Kota Bengkulu. Jurnal Akuntansi Vol. 1 No. 3

Bahri F, M Samsul. (2011). Efisiensi dan Efektivitas Pemungutan Pajak Daerah Kota Surakarta Tahun 2004-2009. Skripsi Strata Satu Fakultas Keguruan dan Ilmu Pendidikan Universitas Sebelas Maret. 